\begin{tabular}{|l|l|l||}
\hline \multicolumn{2}{|c|}{ PublisherInfo } \\
\hline \hline PublisherName & $:$ & BioMed Central \\
\hline \hline PublisherLocation & $:$ & London \\
\hline \hline PublisherImprintName & $:$ & BioMed Central \\
\hline \hline
\end{tabular}

\title{
Gene acquisition in eukaryotes
}

\begin{tabular}{|l|l|l||}
\hline \multicolumn{2}{|c|}{ ArticleInfo } \\
\hline \hline ArticleID & $:$ & 4780 \\
\hline \hline ArticleDOI & $:$ & $10.1186 /$ gb-spotlight-20030528-01 \\
\hline \hline ArticleCitationID & $:$ & spotlight-20030528-01 \\
\hline \hline ArticleSequenceNumber & $:$ & 132 \\
\hline \hline ArticleCategory & $:$ & Research news \\
\hline ArticleFirstPage & $:$ & 1 \\
\hline \hline ArticleLastPage & $:$ & 2 \\
\hline \hline & & RegistrationDate : 2003-5-28 \\
\hline ArticleHistory & $:$ & OnlineDate \\
\hline \hline ArticleCopyright & $:$ & BioMed Central Ltd2003-5-28 \\
\hline \hline ArticleGrants & $:$ & \\
\hline \hline ArticleContext & $:$ & 130594411 \\
\hline \hline
\end{tabular}




\section{L Bishop}

Email: cleo.bishop@imperial.ac.uk

Chlorarachniophytes are marine protists that have acquired photosynthetic capacity by engulfing and retaining a chlorophyte green alga through secondary endosymbiosis. This process has been an important factor in eukaryotic evolution, yet the number and timing of these events remains unresolved. One of the main results of secondary endosymbiosis has been the movement of the genes encoding plastid-targeted proteins from the endosymbiont nucleus to that of the host.

In the early edition of Proceedings of the National Academy of Sciences, John Archibald and colleagues from The Canadian Institute for Advanced Research describe phylogenetic analysis of several plastid-targeted proteins from a chlorarachniophytes. They show that a significant number of genes have been acquired through lateral gene transfer from numerous sources, but that the genes of the chlorophyte Chlamydomonas reinhardtii show no evidence of lateral gene transfer (PNAS, DOI:10.1073/pnas.1230951100).

Archibald et al. screened nearly 4,000 ESTs (expressed sequence tags) from the chlorarachniophyte Bigelowiella natans and identified $78 \mathrm{cDNAs}$ encoding putative plastid-targeted proteins. By means of alignment and phylogenetic analysis, they established that the majority were derived from a chlorophyte of green algal origin. But $21 \%$ of the proteins had phylogenetic affinities that indicated they were from a source other than the endosymbiont. These genes had been acquired by lateral gene transfer from a variety of sources, including streptophyte algae, red algae, algae with red algal endosymbionts and even bacteria. Similar analysis of the chlorophyte Chlamydomonas reinhardtiishowed no evidence of lateral gene transfer.

"There is no obvious reason to assume that the acquisition of foreign genes by chlorarachniophytes is limited to those involved in plastid function. Whether lateral transfer will prove to be as important in eukaryotes as in prokaryotes remains to be seen... At present, it seems that lateral gene transfer has been a factor in the evolution of eukaryotic genomes, but that its impact may very from lineage to lineage," conclude the authors.

\section{References}

1. Jam packed genomes - a preliminary, comparative analysis of nucleomorphs.

2. Proceedings of the National Academy of Sciences USA, [http://www.pnas.org/]

3. The Canadian Institute for Advanced Research, [http://www.ciar.ca] 